\title{
PARTHENOGENESIS IN THE PEAR-SLUG SAW-FLY.
}

By H. E. Ewing, Iowa State College, Ames, Iowa.

\section{INTRODUCTORY.}

But few of our economic insects have been studied more than the common pear-slug or cherry-slug saw-fly, Caliroa cerasi Linn., yet concerning some points in its biology and life history we are as yet in doubt. Parthenogenesis, known to occur in some of the saw flies, has been suspected in the case of this species, but does not appear to have been sufficiently proved. Mr. R. L. Webster, in his bulletin on this pest* presents a good account of its biology and life history, but in regard to parthenogenesis (complete and successful) he states that it had not been sufficiently proved, yet some important observations were made which are mentioned in this paper.

\section{Rarity OF THE Males.}

Males of the pear-slug saw-fly have been described, and were at one time supposed to be fairly common. Mr. Webster, however, noticed early in his work with the species the apparent absence of the males around Ames, Iowa. On page 181 of his bulletin he states: "We have collected and examined large numbers of saw-flies, but have never found a male." $\mathrm{He}$ also wrote to Mr. S. A. Rohwer, of the U. S. National Museum in regard to the rarity of the males. Mr. Rohwer examined the collection of the museum, and reported that there were no maies there, either from Europe or from America. While working at the Iowa Station in 1911, and while at the Oregon Station, 1911-14, I had occasion to examine hundreds of these saw-flies but never found a male. It appears then that if males exist in this country, they must be very rare in certain localities.

Caliroa cerasi differs from many of the saw-flies in respect to the numerical ratios of the sexes, for in some of the species the males are present in abundance, and mate normally with the females. This was shown to be the case with the cherry

\footnotetext{
*Webster, R. L. The Pear-slug. Bul. No. 130, Iowa Agric. Exp. Sta. (1912).
} 
and hawthorn saw-fly leaf-miner, Profenusa collaris MacGillivray, by Parrott and Fulton. $\dagger$ In this regard they give the following: "Out of doors the females appeared in larger numbers at a somewhat earlier period than the males, but judging from collections taken at irregular intervals it does not appear that marked numerical differences existed between the sexes. To all appearances the adults copulated freely. In one breeding cage, containing no males, two females made their appearance, and these were isolated and supplied with cherry twigs to induce oviposition. This they did, and five days later three eggs hatched. This experience suggests that fertilization is not absolutely necessary for the development of the eggs and also indicates that parthenogenesis may occur, although it is perhaps not an important factor in the life of the species."

\section{Experiments at the Iowa Station.}

Webster in his bulletin states that parthenogenesis probably occurs in the pear-slug saw-fly, but that it had not been satisfactorily proved. However, he showed that virgin females would deposit eggs and that these eggs would hatch; yet none of the larvæ hatching from parthenogenetic eggs was reared to maturity. In regard to these experiments, Webster states: "Both Mr. Ness and Mr. McCall confined virgin female sawflies in insectary cages and obtained eggs from them. Some of these eggs hatched, but the larvæ were weak and in no case did they live more than a few days. None reached the second stage." These experiments seemed to show that there was not a complete normal parthenogenesis like that which exists in the plant lice, or in fact in the case of some of the other species of saw-flies, but a type similar to that known to exist in the silk worm, where only a few unfertilized eggs hatch, and the issuing larvæ never reach maturity.

\section{Breeding Experiments CARRIEd ON BY the Writer.}

During the month of May, 1913, while rearing the black cherry aphis, Myzus cerasi Fab., as food for Coccinellidæ, the life histories of which I was studying, three females of Caliroa cerasi emerged in the aphid breeding cages. These breeding

†Parrott. P. J.. and Fulton, B. B. The Cherry and Hawthorn Sawfly Lea-j Miner, Bul. No. 411, New York Agric. Exp. Sta. (1915). 
cages were quite large, being about three fcet high and over three feet in diameter, and each was placed over a young cherry tree that had been cut back so as to be enclosed by the cage. They were out-of-door cages without bottoms, so that any insects emerging from the soil would be caught. On June 6th I observed that two females had emerged in one of the cages which I designated as cage $\mathrm{A}$, and in another, one female saw-fly had emerged. This second cage was designated as cage $\mathrm{B}$. These virgin females began to oviposit almost at once, and by June 15 , in cage A, I noted several eggs and six young larvæ, and in cage $B$ another female had emerged, and a few eggs were observed but no young slugs. By July 5, the females had died in cage A, many growing slugs were present but no pupæ. These larvæ continued to grow, and feed in a normal manner, and then to pupate.

On July 31 I noticed the first adult of the second generation $\left(\mathrm{F}_{1}\right)$ had emerged. It was very active, and was moving about the upper side of the cage. From now on adults from the parthenogenetic eggs of the first generation females continued to emerge rapidly.

In all, 34 adult individuals were obtained from the parthenogenetic eggs of the two females in cage A. All of them were females, and all were healthy, active and vigorous.

As fast as these females emerged they were isolated and each placed in a gauze-bag breeding cage, which was placed around the end of a cherry branch. These gauze bags were of sufficient size to allow the females considerable freedom, and were placed over the branches several weeks earlier after every leaf had been carefully examined for foreign eggs. This was a precaution against contamination, the bags excluding all the other sawflies in the orchard.

Some of the data obtained for the rearing of these parthenogenetic individuals are here presented in tabular form. 
TABLE I.*

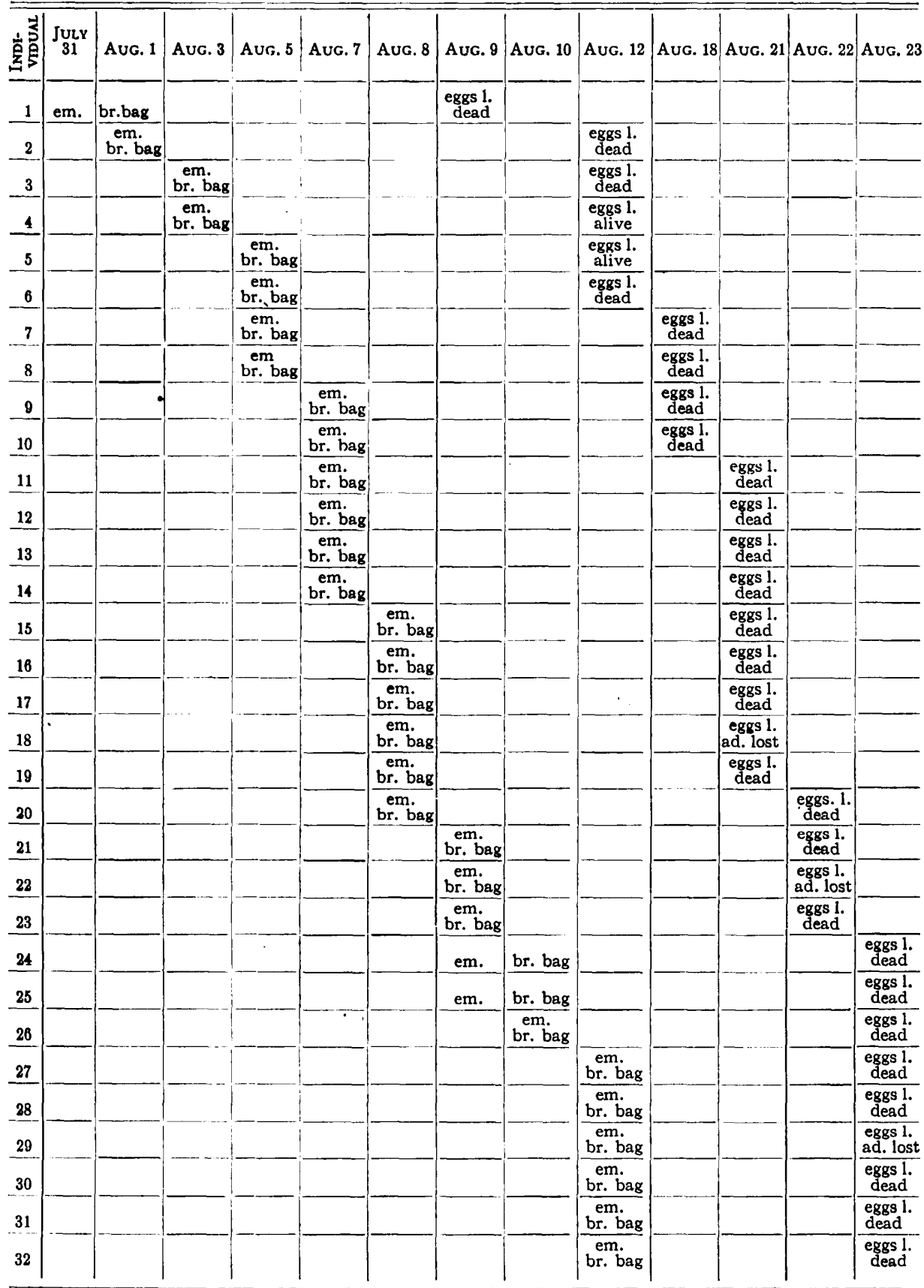

The abbreviations used in this table are explained as follows: em.-adult emerged; br. bag-placed in breeding bag; eggs 1. —eggs laid; ad. lost-adult lost. 
From this table we observe that all of the 32 virgin females that were reared from the eggs of the 2 first-generation virgin females laid eggs. Since the breeding cages used up to this time were out-of-door cages these observations give us some insight into the seasonal history of the species. The first adult of the second generation to emerge came out on July 31, the last on August 12. Eggs of the second generation adults were first observed August 9. The first record of a death of the second generation adult was August 9. By August 23 all of the adults of the second generation were dead. The period of longevity appears to be quite short for these second generation adults.

The progeny of four of these second generation adults was saved, and reared in four separate breeding cages. Some of the data for these four experiments are given in tabular form in the following table.

TABLE II.

\begin{tabular}{|c|c|c|c|c|c|}
\hline $\begin{array}{l}\text { Olirspring } \\
\text { OF FEMALE }\end{array}$ & $\begin{array}{l}\text { LARVAE } \\
\text { ISOLATED }\end{array}$ & $\begin{array}{l}\text { WHEN } \\
\text { ISOLATED }\end{array}$ & $\begin{array}{l}\text { Notes For } \\
\text { OCT. } 5\end{array}$ & $\begin{array}{c}\text { Notes For } \\
\text { FER. } 16\end{array}$ & Notes For June 28 \\
\hline No. 2 & 30 & Sept. 11 & In soil & & \\
\hline No. 8 & 30 & Sept. 15 & In soil & $\begin{array}{l}3 \text { pupae } \\
\text { found } \\
2 \text { alive }\end{array}$ & $\begin{array}{l}1 \text { dead adult on top of soi.. } \\
3 \text { dead larvae in earthern cells } \\
3 \text { dead pupae in earthen cells. } \\
7 \text { dead adults in earthen cells. }\end{array}$ \\
\hline No. 14 & 33 & Sept. 17 & In soil & & Empty earthen cell observed. \\
\hline No. 25 & 16 & Sept. 27 & In soil & & $\begin{array}{l}3 \text { dead larvae in earthen cells. } \\
3 \text { dead pupae in earthen cells. } \\
3 \text { dead adults in earthen cells. }\end{array}$ \\
\hline
\end{tabular}

The results from these four breeding cages were surprising. Of the large number of larvæ obtained (109) during the fall only a single adult emerged the following spring. Examinations during the winter showed that most of the larvæ had pupated and were alive. Later on I made a very thorough search in the soil for predaceous enemies, but found none that I suspected of preying on the larvæ or pupæ. In fact the final examination on June 28 showed that the earthen cells were intact. Of the 23 earthen cells found on this day, 10 contained the mature dead saw-flies. They had passed through their transformations in good shape, but for some reason did not emerge from their earthen cells.

Can it be that parthenogenesis when continued into the second generation descendants causes a great diminution in the vitality of the race? 
Observations in the orchard where the first virgin females were obtained showed that the conditions there were similar to those of my experiments. During the first year there were large numbers of the first generation females present, but I did not observe a single male, hence infer that practically all of the eggs laid were unfertilized. These females laid an enormous number of eggs, and apparently almost all of them hatched, for seldom have I seen cherry trees more heavily infested than were these trees during the summer of 1913. The injury was so great that several of the younger trees were killed outrightsomething unusual in the case of saw-fly infestation. Yet in this same orchard the following spring, scarcely a saw-fly emerged. On June 7 , I examined the orchard thoroughly, and did not find an adult or a single egg. It was June 20 before I found eggs, and then only a few of them. The slugs that developed in this orchard in 1913 were very few, and were of no importance from an economic standpoint, in fact most of the trees were absolutely free from them.

Could it be that climatic conditions killed the saw-flies in this orchard and in my cages? During the spring of 1913 we had a very warm spell in March, and later a cold snap. Could this warm spell have so hurried the development of the sawflies that they were later killed by the cold? I think not, for in other places in the same vicinity the saw-flies came out in abundance. One orchard, only a few miles away, was badly infested and injured the same spring. Could the saw-flies have been killed by a fungous disease? None whatever was detected. Even the bodies of dead individuals were usually free from fungi. Could it be that the ground was so hard during the emerging period that the adults could not make their way out? I hardly think so. At first I suspected this as being the reason, but after keeping the ground soft in two of my breeding cages for many days, I did not get a single saw-fly to emerge. Besides the thorough examination of the earthen cells showed that the adults did not even get out of them.

It appears then that we must look elsewhere in order to find the causes for the non-emergence of these second generation parthenogenetic adults. Judging from the facts collected during my investigations of this species, I am inclined to the opinion that parthenogenesis while normal and completely advantageous for the species in the spring parthenogenetic 
generation, when continued into the second generation causes a great diminution in the vigor of the individuals. Some of these second generation individuals die in the larval stage; some, as shown in my experiments, in the pupal stage; and many of them in the adult stage inside of the earthen pupal cases.

\section{SUMMARY.}

1. The males of our common pear- or cherry-slug saw-fly must be very rare in certain parts of our country. The examination of several hundreds of individuals obtained at various times during the late spring and summer for three seasons at Ames, Iowa, and for two seasons at Corvallis, Oregon, failed to reveal a single male.

2. The species is parthenogenetic, and successfully so for the offspring of the spring brood of females.

3. The eggs deposited by spring-brood virgin females hatch, and produce normal vigorous larvæ. These feed normally, later pupate and finally produce adults.

4. Unfertilized eggs produce females only.

5. Parthenogenesis when continued for the offspring of the second or summer brood of adults, gave larvæ, a considerable percentage of which failed to pupate, a considerable percentage successfully pupated, but did not transform into the adult stage, and a very large percentage transformed into adult stage, but did not emerge from the enclosing earthen cells.

6. Only a single adult was reared from 109 of the second generation parthenogenetic larvæ.

7. An orchard which was heavily infested with springbrood females, and in which no males were observed, produced an enormous number of second generation females, which produced in turn an increasing number of second brood larvæ, causing injury so serious as to kill outright several cherry trees of the orchard and to seriously injure all of the trees. From this enormous second brood of larvæ only a very few adults emerged the following spring.

8. I am unable to account for the failure of these second brood larvæ to produce active adults unless it be on account of a lack of vigor due to the absence of fertilization for this brood, yet it is possible that this failure was due to other causes. 